\title{
Genetic Diversity of Eurycoma longifolia Jack Based on Random Amplified Polymorphic DNA Marker
}

\author{
Rosmaina, Zulfahmi* \\ Department of Agrotechnology, Faculty of Agricultural and Animal Science, State Islamic University of Sultan Syarif Kasim \\ Riau, UIN SUSKA Riau Campus at Panam, PO BOX 1004, Pekanbaru 28293, Riau, Indonesia
}

Received January 22, 2013/Accepted June 11, 2013

\begin{abstract}
Eurycoma longifolia Jack is one of the extensively exploited medicinal plants in Indonesia. The objectives of this study were to obtain information on genetic diversity and population genetic structure of E. longifolia to formulate effective conservation plan. RAPD marker was used to assess the genetic diversity of E. longifolia collected from 5 natural populations in Riau Province. A total of 25 plants were analyzed using 5 RAPD primers, which amplified produced 44 scored DNA bands. The mean observed number of alleles per locus (No), number of effective alleles $(\mathrm{Ne})$, and percentage of polymorphic loci (PPL) of E. longifolia were 1.57, 1.34, and 56.80\%, respectively. The degree of differentiation among populations of E. longifolia was $0.31(\mathrm{Ht}=0.29 ; \mathrm{Hs}=0.20)$. The mean value of estimated gene flow among populations of E. longifolia was 1.11 individual per generation. The UPGMA dendogram formed 2 significant clusters. The first cluster consisted of Pelalawan and Kampar populations, while the second cluster was formed from Kuansing, Rohul, and Rohil population. The genetic diversity information in this study is very important to perform efficient conservation and effective future management of its genetic resources.
\end{abstract}

Keywords: Eurycoma longifolia, RAPD marker, genetic variation, conservation

*Correspondence author, email:fahmi2509@gmail.com, tel.+62-761-562051,fax: +62-761-562052.

\section{Introduction}

Eurycoma longifolia Jack is a member of Simaroubaceae family and is widely distributed in South East Asia. It is identified locally as pasak bumi in Indonesia, tongkat ali in Malaysia, Ian-don in Thailand, and 'Cay ba binh' in Vietnam (Osman et al. 2005). In Indonesia, E. longifolia can be found in Sumatra and Kalimantan forests at an altitude $<700 \mathrm{~m}$ asl. E. longifolia is a small grown tree reaching up to $15 \mathrm{~m}$ in height and $15 \mathrm{~cm}$ in diameter. It is well grown in acid, sandy, and low nutrient soils and is often found among dipterocarps species (Hadiah 2000). E. longifolia is an economically important plant that is as a source of herbal medicine. The root extract of $E$. longifolia is known to contain biologically active compound that can be widely utilized as antimalaria (Chan et al. 2005), to inhibit growth of human breast cancer cell line (Tee \& Azimahtol 2005), to increase testosterone hormone level (Tambi et al. 2011), to protect bone calcium loss (osteoporosis) (Effendi et al. 2012), and as insecticide (Lina etal. 2009).

The high demand of E. longifolia for pharmaceutical has impacted on the increased harvesting of E. longifolia in their natural habitats. Over-exploitation of natural stands by medicinal plants collectors associated with low efficiency in seed production and germination of E. longifolia has caused depletion of this species in nature. Furthermore, the rate of deforestation in Indonesia tropical forests that has reached
0.8 million hectares annually (MoF 2012) due to illegal logging, forest fire and conversion into agricultural, settlement, and industrial lands have also caused the declining in numbers size and threatening the genetic diversity of $E$. longifolia in nature. In Indonesia, $E$. longifolia has now been declared as a protected species based on Regulation of Ministry of Agriculture No. $511 / \mathrm{Kpts} / \mathrm{PD} .310 / 9 / 2006$, as the over collection of this species in the wild has almost caused its extinction from the forest. Therefore, efforts to conserve the genetic resource of E. longifolia have become a priority. Preservation of genetic variation and evolutionary process in viable populations has an ecological importance of preventing the potential extinction for $E$. longifolia.

Until now, very little information on genetic variation of E. longifolia is available in Indonesia. The only known report is only by Susilowati (2008) who applied RAPD (random amplified polymorphic DNA) markers on $E$. longifolia collected from Jambi, whereas information of genetic variation of $E$. longifolia in Riau Province has not yet been reported. Therefore, this study is necessary to be implemented as a basic consideration for formulating the effective and efficient conservation strategy and utilization of genetic resource of E. longifolia in Riau Province in future.

Currently, several DNA molecular markers have been 
developed for plant genetic analysis, one of such is RAPD markers. RAPD markers has been one of the most commonly used techniques for estimating the genetic diversity in plant population due to their advantages compared to other DNA molecular techniques such as its simplicity, fast, low cost, require small amounts of target DNA, no need of prior sequences information on target species, radioactivity free procedure, and fast providing information on plant genetic (Welsh \& McClelland 1990; Williams et al. 1990; Spooner et al. 2005; Weising et al. 2005; Muchugi et al. 2008). The use of RAPD markers in population genetic studies has been well established for forest tree species such as Melia volkensii (Runo et al. 2004), palahlar (Sumiyati et al. 2009), Terminalia (Deshmukh et al. 2009), Dalbergia sissoo (Wang et al. 2011), Pterocarpus angolensis (Amri \& Mamboya 2012), and others. Although RAPD has limitation, such as dominant properties, several strategies have been put forward to minimize the effects of dominance on genetic variation analysis (Lynch \& Milligan 1994). In occasional cases RAPD is considered poor in reproducibility. However this weakness can be resolved by optimizing the reaction condition (Weising et al. 2005; Muchugi et al. 2008). According to Lynch and Milligan (1994) although RAPD markers have limitations as mentioned above, this marker can provide valuable genetic variation data within and among species population of plants. The objective of this study is to assess the genetic variation and genetic population structure of E. longifolia using RAPD markers.

\section{Methods}

A total number of 5 individual sample of $E$. longifolia young leafs were collected from natural forest in 5 districts in Riau Province, namely Kampar District (Kampar), Rokan Hulu Dictrict (Rohul), Rokan Hilir District (Rohil), Pelalawan District (Pelalawan), and Kuantan Singingi District (Kuansing) for DNA isolation. The leaf samples collected were placed in plastic packages containing silica gel with a ratio of leaf to silica gel of 1:5 $(\mathrm{w} / \mathrm{w})$ to reduce the leaf moisture content and prevent from fungi attack. Subsequent samples were carried to laboratory and stored in a freezer at temperature of $-20^{\circ} \mathrm{C}$ until DNA extractions were performed.

Genomic DNA was isolated from leaf tissues using modified CTAB (cetyltrimethyl ammonium bromide) method (Doyle \& Doyle 1990). The quality of DNA isolation was determined by agarose gel electrophoresis of $0.8 \%(\mathrm{w} / \mathrm{v})$. Electrophoresis was performed using $1 \times$ Tris Acetate EDTA (TAE) buffer for about 30-45 minutes at 100 volt. The gel was stained with ethidium bromide solution of $0.5 \%(\mathrm{v} / \mathrm{v})$ for $15-20$ minutes at room temperature, and then washed with distilled water for 10 minutes. The banding patterns of gel were observed under UV light apparatus and gel documentation was carried out using Gel Doc system (BioRad).

Primer selection, amplification, and DNA electrophoresis Twenty random primers were initially screened to determine the suitability of each primer for the study. DNA isolation results were bulked and used as sample for primer selection. Two samples for each primer and a negative control were amplified. The DNA amplification was performed in CFX
96TM Real Time DNA engine Thermal cycler (BioRad). The amplification was programmed as follows: initial denaturation for 5 minutes at $95^{\circ} \mathrm{C}$, followed by 45 cycles of denaturation for 1 minute at $95^{\circ} \mathrm{C}$, annealing for 1 minute at $36^{\circ} \mathrm{C}$, extension for 1 minute at $72^{\circ} \mathrm{C}$, and final extension for 10 minutes at $72^{\circ} \mathrm{C}$. The PCR reaction was as following and made up of $13 \mu \mathrm{l}$ in volume, containing $2.0 \mu \mathrm{l}$ DNA template (5-10 ng), $1.5 \mu \mathrm{l}$ primer $(5 \mathrm{pmol} / \mu \mathrm{l}), 2.0 \mu \mathrm{l}$ water free RNase, and $7.5 \mu$ l HotStar Taq Master Mix (Qiagen). PCR products were separated through electrophoresis on a $2.0 \%$ $(\mathrm{w} / \mathrm{v})$ agarose gel in $1 \mathrm{X}$ TAE buffer at 100 volt for about 30 45 minutes, and then gels were stained in $0.5 \%(\mathrm{v} / \mathrm{v})$ ethidium bromide solution. The banding patterns of gel were observed under UV light apparatus and photographed using Gel Doc system (BioRad). A 100 bp DNA ladder (Amresco) was included in the gels as a size reference or molecular weight standard. Analysis of banding patterns was performed using an Image Lab version 2.0.1 (BioRad) Software.

Data analysis Amplification products were scored as ' 1 ' for presence and ' 0 ' for absence of each band in individual lanes. The scores were entered as a binary matrix for analysis. The following genetic diversity parameters were calculated: percentage of polymorphic loci (PPL), the number of alleles per locus (No), the effective number of alleles per locus (Ne), genetic variation (Nei's gene diversity, He), genetic differentiation among populations (GST), genetic distance (do), and gene flow (Nm). All parameters were calculated using the software of POPGEN version 1.31 (Yeh et al. 1999). Analysis Molecular of Variance (AMOVA) was also carried out to estimate the variance component among and within populations using the software of ARLEQUIN version 2.00 (Schneider et al. 2000). UPGMA (Unweighted Pair-Group Method Arithmatic) dendogram analysis based on Nei's genetic distance (1972) was calculated using NTSYS version 2.00 (Rohlf 1998) software.

\section{Results and Discussion}

Twenty primers were initially tested and 5 were selected, namely OPO-06, OPD-03, OPD-13, OPY-16 and OPY-20 for further analysis due to their clear DNA band patterns and high polymorphism. PCR amplification products from the 5 primers selected have generated 44 DNA fragments. The band number per primer ranged $8-10$ and band sizes ranged 100-1600 bp (Table 1), depending on primer type used and sampled genotype. Amplification products generated by OPO-06 primer are shown in Figure 1.

No, Ne, PPL, and He of E. longifolia are shown in Table 2 . No value ranged 1.14 (Rohul population)-1.71 (Kuansing population), with an average of 1.57. Ne value ranged 1.221.48 , with an average of 1.34. The Rohul population $(\mathrm{Ne}=$ 1.22) had the lowest value observed and the Kuansing population $(\mathrm{Ne}=1.48)$ showed the highest value obtained. The higher PPL value of E. longifolia was observed in Kuansing population (70\%) and the lower PPL value was observed in Rohul population $(41 \%)$, with an average of $56.80 \%$. The He of E. longifolia ranged $0.13-0.27$, with an average of 0.20 . The value of $E$. longifolia in this study was similar to the mean value of genetic variat based on RAPD markers for short-lived perennial $(\mathrm{He}=0.20)$, higher than 
Table 1 Primers selected and their sequence, the total number of band, and size range of amplified fragments of Eurycoma longifolia

\begin{tabular}{cccc}
\hline $\begin{array}{c}\text { Name of } \\
\text { primer }\end{array}$ & Sequence of the primers & Total number of band & Size range (bp) \\
\hline OPD - 03 & 5' GTCGCCGTCA '3 & 8 & $300-1500$ \\
OPD - 13 & 5' GGGGTGACGA '3 & 9 & $200-1500$ \\
OPO - 06 & 5' CCACGGGAAG '3 & 9 & 200-1600 \\
OPY - 16 & 5' GGGCCAATGT '3 & 8 & $100-1000$ \\
OPY - 20 & 5' AGCCGTGGAA '3 & 10 & 100-1200 \\
\hline
\end{tabular}

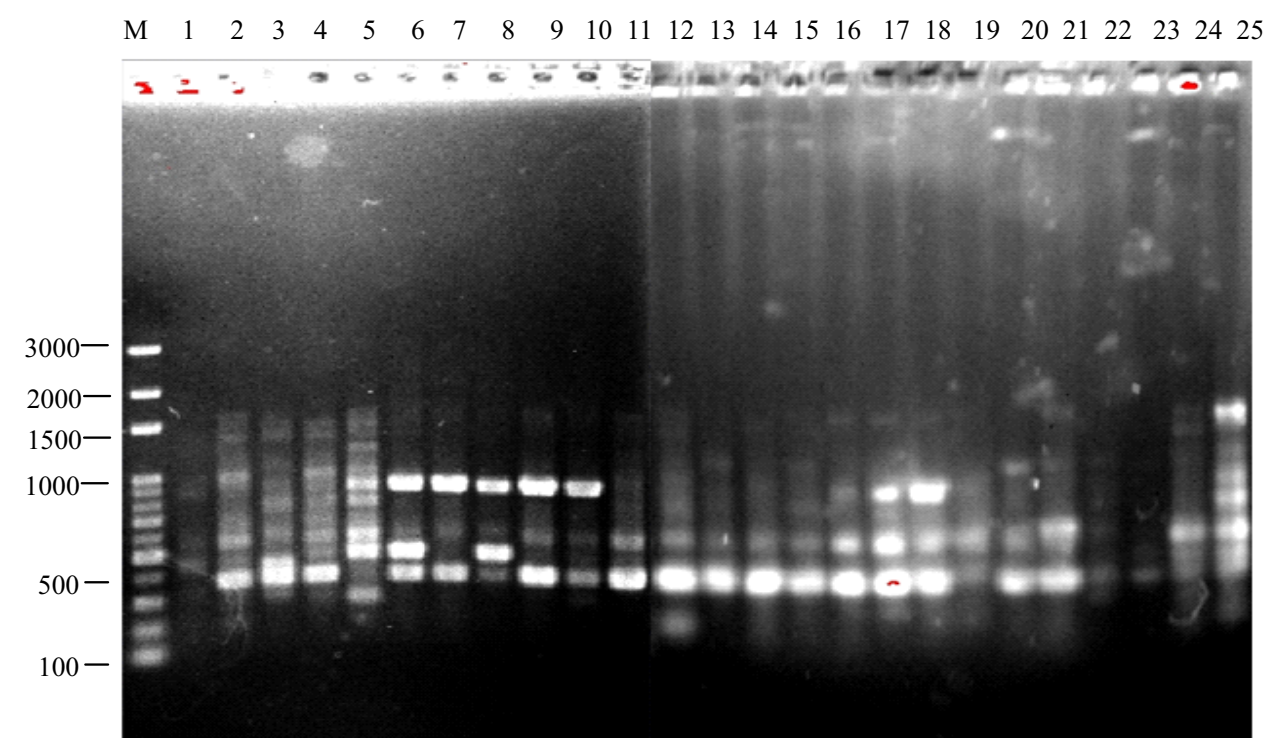

Figure 1 RAPD amplification products of OPO-06 primer, [1-5] Kuansing, [6-10]Rohul, [11-15] Rohil, [16-20], Kampar, and [21-25] Pelalawan population.

Table 2 Genetic variation indices for 5 E. longifolia populations

\begin{tabular}{lccccc}
\hline Population name & $\mathrm{N}$ & $\mathrm{N}_{\mathrm{o}}$ & $\mathrm{N}_{\mathrm{e}}$ & PPL (\%) & $H_{e}$ \\
\hline Pelalawan & 5 & 1.64 & 1.35 & 63.64 & 0.21 \\
Kampar & 5 & 1.52 & 1.31 & 52.29 & 0.18 \\
Rohil & 5 & 1.57 & 1.36 & 56.82 & 0.21 \\
Rohul & 5 & 1.41 & 1.22 & 40.91 & 0.13 \\
Kuansing & 5 & 1.71 & 1.48 & 70.45 & 0.27 \\
\hline Average & 5 & 1.57 & 1.34 & 56.80 & 0.20 \\
\hline N: samples size; $\mathrm{N}_{\mathrm{o}}$ : number of alleles per locus; $\mathrm{N}_{\mathrm{e}}$ effective number of alleles per locus; PPL: &
\end{tabular}

selfing plant $(\mathrm{He}=0.12)$ and lower than outcrossing species $(\mathrm{He}=0.27)($ Nybom 2004). Genetic variation value of $E$. longifolia in this study was found to be lower than the genetic variation value of E. longifolia by Susilowati (2009) $(\mathrm{He}=$ 0.31 ) based on RAPD markers, due to the low percentage of polymorphic loci value in this study $(56.80 \%)$. Susilowati (2009) obtains a $78.57 \%$ of polymorphic loci, and used different addition number and primers' type. The genetic variation values of $E$. longifolia in this study was quiet similar to the results of study by Osman et al. (2005) using Single Nucleotide Polymorphisms (SNP) markers (He = 0.22 ). However, the relevancy of this comparison may be questioned since the studies were conducted using different molecular markers, e.g. RAPD and SNP. In RAPD study, genetic variations was determined through allele frequencies, average allele number, heterozygosity, and percentage of polymorphic loci, etc, whereas in SNP study, genetic diversity level was determined by means of heterozygosity and percentage of polymorphic loci. Allele frequency and mean number of polymorphic alleles were excluded from calculation since SNP technique was developed to detect only 2 different alleles (Osman et al. 2005).

Genetic variation is an important feature of plant species, especially for the ability of forest trees to adapt and evolve through environmental changes so that they can thrive and be stable for a long time. According to Machua et al. (2007) populations with high level of genetic variations are valuable 
since they offer a diverse gene pools that are useful for genetic conservation and breeding programs. The declining genetic variation would restrict a species ability to keep face with the changing environment and their roles in the ecological and evolutionary development of the biosphere (Runo et al. 2004; Machua et al. 2007). Consequently, maintenance of genetic diversity is considered vital as diversity carries forward both ecological adaptation and microevolution.

GST of E. longifolia was found to be $0.31(\mathrm{HT}=0.29$; HS $=0.20)$. The GST values indicated that $31 \%$ of the total genetic variation was found among populations, whereas $69 \%$ of genetic variation was maintained among individuals within populations. High level of genetic variation found within population would serve as consideration for conservation purposes to capture the maximum genetic variation within species. The GST value in this study was higher than average value of that of tropical tree forests (GST $=0.12)$ and forest trees in temperate zones $(\mathrm{GST}=0.09)$ (Dick et al. 2008). Genetic variation and it's partitioning among and within populations of plant species were determined by a number of factors, where reproductive biological system (selfing vs outcrossing) as the most significantt. Data summarized from RAPD markers has provided a mean GST of $<23 \%$ for outcrossing species, and GST $>59 \%$ for inbred species (Nybom \& Bartish 2000; Nybom 2004). The genetic differentiation among $E$. longifolia populations ( $\mathrm{GST}=31 \%$ ) was neither in the range of outcrossing nor inbred species.

The GST values can be classified into 3 levels, e.g. low $(\mathrm{GST}=<0.05)$, moderate $(\mathrm{GST}=0.05-0.15)$, and high (GST $=>0.15)($ Nei 1978), hence GST values of $E$. longifolia obtained in this study is considered as high. High GST value indicated that gene flow is restricted via pollen or seed. Seed of E. longifolia is relatively heavy and big so that seed dispersal is limited on forest floor, where most were found close to parent trees (Keng et al. 2002; Osman et al. 2005). High GST value could also be explained by the low density of E. longifolia within the sampling area. E. longifolia is difficult to obtained and when found, they were often grouped near parent trees. Such condition would influence the mating system and gene flow of E. longifolia. According to Finkeldey (2003), tree populations with low densities had higher GST values than those of high densities.

The AMOVA results indicated that $22.34 \%$ of the total genetic variation was found among populations and $77.66 \%$ was found within population (Table 3). All molecular variance components were significant $(p<0.001)$. It can be concluded that most of the genetic variations of $E$. longifolia were maintained within the population. Hamrick et al. (1992) report that woody perennial species generally maintain most of their variation within population, which holds true for tropical trees in particular. Generally, the mating system of flowering plant species greatly affects population genetic differentiation (Hamrick \& Godt 1989). The estimates of genetic differentiation between the populations for outcrossing species based on AMOVA, derived by analyzing
RAPD markers are usually $<28 \%$. For inbred species, estimates of interpopulation genetic variation are usually $>$ $65 \%$ (Nybom \& Bartish 2000; Nybom 2004). The genetic differentiation between the populations of E. longifolia $(22.34 \%)$ was in the range of outcrossing species. $E$. longifolia is a predominant outcrossing; this is supported by observation on flower morphology in greenhouse, which showed that E. longifolia has unisexual flowers, the male flowers always with a sterile pistil, and female flowers always with sterile stamens

Gene flow is one of an important parameter for determination of genetic variation of plant. According to Govindaraju (1989) that gene flow values can be differentiated into 3 levels, high $(\mathrm{Nm}>1)$, moderate $(0.25<$ $\mathrm{Nm}<0.99)$, and low $(\mathrm{Nm}<0.25)$. Gene flow among populations of $E$. longifolia in our study was 1.11 individual per generation and belong to high category. Lacerda et al. (2001) stated that $\mathrm{Nm}$ values above 1.0 are common among populations of tropical trees. These relatively high values of $\mathrm{Nm}$ expected for tropical trees are probably associated with the fact that many pollen and seed vectors for these species are capable of walking or flying long distances. Gene flow is determined by pollinators, seed dispersers, stand density, flowers phenology, gender distribution, outcrossing rates, and inbreeding depression (Dick et al. 2008). If we compared to gene flow others species, $\mathrm{Nm}$ values of $E$. longifolia in this study is almost similar to Iris japonica $(\mathrm{Nm}$ $=1.28$, Yong et al. 2012), lower then gene flow of Dalbergia sissoo $(\mathrm{Nm}=3.31)$ with outcrossing and insect pollinators but seed dispersal is assisted by wind (Wang et al. 2010) and gene flow of Maesopsis eminii $(\mathrm{Nm}=11.11$, Zulfahmi 2007) outcrossing species with seed dispersed by hornbill, rodents, and bats.

Genetic distance indicated the genetic relationship among E. Longifolia populations, where the genetic distance values ranged from $0-1$ (Finkeldey 2003). The genetic distance values among populations of E. longifolia ranged from 0.1157-0.2109 (Table 4). The maximum value was observed between Kampar and Kuansing populations, while the minimum value was observed between Rohil and Rohul populations. UPGMA dendogram based on Nei's genetic distance (1972) displayed that five populations of $E$. longifolia were divided into two groups (Figure 2). The first cluster consisted of Kampar and Pelalawan populations, and second cluster consisted of two subgroups, the first was Rohil and Rohul populations, and second was Kuansing population. Rohil and Rohul populations had closely genetic relationship because both populations were closely located hence allowed for the movement of genetic materials between populations, through human intervention or biotic and abiotic factors. Therefore the migration rates of seeds and pollens of E. longifolia were necessary to be studied in more detail.

Conservation strategy of $\boldsymbol{E}$. longifolia The goals of genetic resources conservation are to reserve and maintain the maximum genetic variation to prevent species

Table 3 Analysis of molecular variance (AMOVA) among and within populations of E. longifolia

\begin{tabular}{lccllc}
\hline Variation source & $\begin{array}{l}\text { Degrees of } \\
\text { freedom }\end{array}$ & $\begin{array}{l}\text { Sum of } \\
\text { Squares }\end{array}$ & $\begin{array}{l}\text { Variance } \\
\text { components }\end{array}$ & $\begin{array}{l}\text { Percentage } \\
\text { of variation }\end{array}$ & P Value \\
\hline Among populations & 4 & 59.58 & 1.76 & 22.34 & $<0.001$ \\
Within population & 20 & 122.40 & 6.12 & 77.66 & $<0.001$ \\
\hline Total & 24 & 182.08 & 7.88 & & \\
\hline
\end{tabular}


Table 4 Genetic distances among populations of E. longifolia based on Nei's (1972)

\begin{tabular}{llllll}
\hline Population & Pelalawan & Kampar & Rohil & Rohul & Kuansing \\
\hline Pelalawan & $* * * * *$ & & & & \\
Kampar & 0.1363 & $* * * * *$ & & & \\
Rohil & 0.1232 & 0.1699 & $* * * * *$ & & \\
Rohul & 0.1525 & 0.1893 & 0.1157 & $* * * * *$ & \\
Kuansing & 0.1526 & 0.2109 & 0.1181 & 0.1545 & $* * * * *$ \\
\hline
\end{tabular}

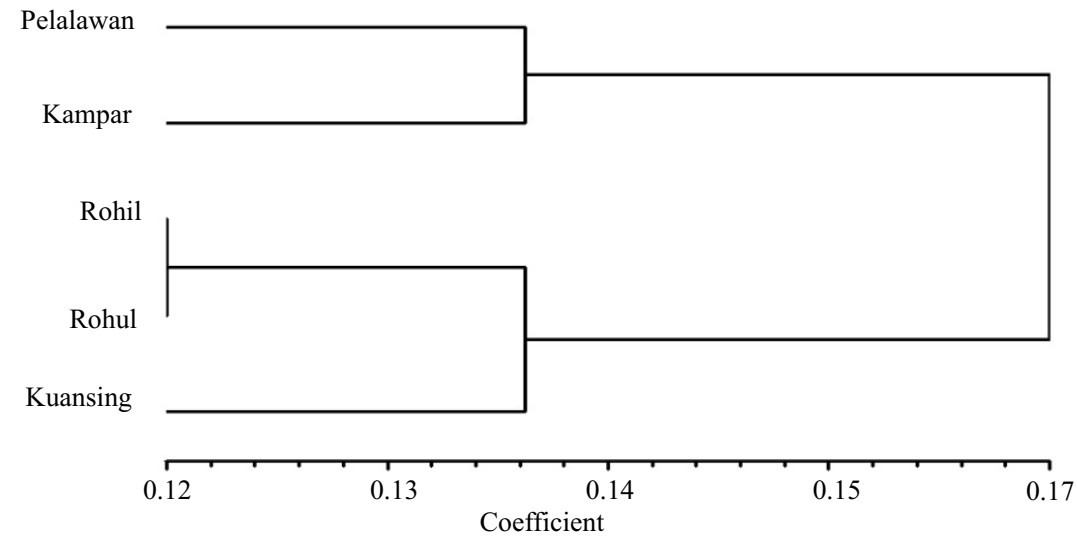

Figure 2 Dendogram of UPGMA cluster analysis on E. longifolia based on Nei's genetic distance (1972).

extinction. Based on genetic information provided from this study, the following conservation strategies of $E$. longifolia were proposed. Conservation of E. longifolia could be carried out in-situ and ex-situ. The in-situ conservation is condicted in natural habitats and useful for capturing the existing local adaptation. If possible, all populations in this study must be conserved due to high genetic variations found within populations. However since each population was separated from the other by distance and financial limitation, thus it would be difficult to manage, it is recommended to conserve the Kuansing population. This population can become the centre of diversity for E. longifolia in Riau Province and subsequently it should be protected by the government to assure their existence. A successful in-situ conservation must fulfil 3 basic requirements as recommended by Koski et al. (1997):

1 regeneration of the population must be assured and the new generation of trees must predominantly come from mating within the conserved population,

2 the number of genotypes in the conserved population must be large enough to include most of the common alleles, and

3 the network of conserved stands must be distributed in such a way as to cover the spatial genetic variation in the species.

The ex-situ conservation of E. longifolia could be conducted outside their natural habitats, such as through monoculture or mixed stands. In establishing ex-situ conservation, the maximum genetic variation and population representatives must be reflected. Based on high GST values obtained in this study, seed sampling must be performed in many populations to capture the maximum genetic variation; in this study, the five populations could become the sampling targets. Ex-situ conservation could also be integrated with tree improvement program thorugh establishment of seed stand provenance and stands of genetic conservation (Finkeldey 2003).

Like other woody species, propagation of E. longifolia through seed is difficult due to quick loss of viability, low seed germination rates and slow growth (Keng et al. 2002; Hussein et al. 2005) which required alternative methods such as stem cuttings and tissue culture for the production of $E$. longifolia for commercial and conservation purposes. Seedling produced should subsequently be reintroduced to original parental population through enrichment planting to increase genetic diversity in natural habitats. Domestication of $E$. longifolia in field plots or demonstration plots was also proposed as an attempt for its conservation and utilization to fulfil the local needs and for additional income through the sales of E. longifolia products. Domestication would also decline the pressures exerted on the natural populations and protect its genetic diversity.

This study resulted in basic genetic information of E. longifolia in Riau Province hence additional information on life history of E. longifolia would be required ptior to the final decision on formulating the genetic conservation and tree improvement of E. longifolia. Therefore, it is recommended to carry further studies on E. longifolia on the:

1 assessment of forest fragmentation impact on genetic structure of E. longifolia,

2 estimation of mating system, outcrossing rates and seed dispersal mechanism of $E$. longifolia,

3 identification of species and behaviour of E. Longifolia pollinators, and

4 improvement of E. longifolia regeneration. 


\section{Conclusion}

The mean of estimated genetic diversity and genetic differentiation among the populations of E. longifolia were 0.20 and 0.31 , while the gene flow was 1.11 individual per generation.

\section{Acknowledgements}

This work was financed by the Institute for Research and Community Development of State Islamic University of Sultan SyarifKasim Riau.

\section{References}

Amri E, Mamboya F. 2012. Genetic diversity in Pterocarpus angolensis populations detected by Random Amplified Polymorphic DNA markers. International Journal of Plant Breeding and Genetics 6(2): 105-114. http://dx.doi.org/10.3923/ijpbg.2012.105.114.

Chan KL, Choo CY, Abdullah NR. 2005. Semisynthetic 15O-acyl- and 1,15-di-Oacyleurycomanones from Eurycoma longifolia as potential antimalarials. Planta Medica 71(10): 967-9. http://dx.doi.org/10.1055/s2005-864188.

Doyle JJ, Doyle JL. 1990. Isolation of plant DNA from fresh tissue. Focus 12: 13-15.

Deshmukh VP, Thakare PV, Chaudhari US, Gawande PA, Undal VS. 2009. Assessment of Genetic Diversity among Terminalia Species Using RAPD Markers. Global Journal of Biotechnology \& Biochemistry 4 (2): 70-74.

Dick CW, Hardy OJ, Jones FA, Petit RJ. 2008. Spatial Scales of Pollen and Seed-Mediated Gene Flow in Tropical Rain Forest Trees. Tropical Plant Biology 1: 20-33. http://dx.doi.org/10.1007/s12042-007-9006-6.

Effendy NM, Mohamed N, Muhammad N, Mohamad IN, Shuid AN. 2012. Eurycoma longifolia: Medicinal Plant in the Prevention and Treatment of Male Osteoporosis due to Androgen Deficiency. Evidence-Based Complementary and Alternative Medicine 2012: 1-9. http://dx.doi.org/10.1155/2012/125761.

Finkeldey R. 2003. An Introduction of Forest Genetic. Institute of Forest Genetic and Tree Breeding. Universitas Goettingen, Germany.

Govindaraju RD. 1989. Variation in gene flow levels among predominantly self-pollinated plants. Journal of Evolution Biology 2:173-181. http://dx.doi. org/10.1046/j.1420-9101.1989.2030173.x.

Hadiah JT. 2000. Eurycoma longifolia Jack (Pasak Bumi). Eksplorasi 2(4): 6.

Hamrick JL, Godt MJW, Sherman-Broyles SL. 1992. Factors influencing levels of genetic diversity in woody plant s pecies. New Forests 6: 95-124. http://dx.doi.org/10.1007/BF00120641.
Hussein S, Ibrahim R, Kiong ALP, Fadzillah NM, Daud SK. 2005. Multiple shoots formation of an important tropical medicinal plant Eurycoma longifolia. Plant Biotechnology 22: 349-351. http://dx.doi.org/10. 5511/plantbiotechnology.22.349.

Keng CL, Sai ST, Teo CKH. 2002. A preliminary study on the germination of Eurycoma longifolia Jack (Tongkat Ali) seeds. Pertanika Journal of Tropical Agriculture Science 25(1): 27-34.

Koski V, Skrøppa T, Paule L, Wolf H, Turok J. 1997. Technical Guidelines for Genetic Conservation of Norway Spruce (Picea abies (L.) Karst.). Rome: International Plant Genetic Resources Institute. 42 p.

Lacerda DR, Acedo MDP, Filho JPL, Lovato MB. 2001. Genetic diversity and structure of natural populations of Plathymenia reticulate (Mimosoideae), a tropical tree from the Brazilian Cerrado. Molecular Ecology 10: 1143-1152. http://dx.doi.org/10.1046/j.1365294X.2001.01264.x.

Lina EC, Arneti, Prijono D, Dadang. 2009. Insecticidal Potency of Pasak Bumi (Eurycoma longifolia Jack) against Cabbage Pest Crocidolomia pavonana (F.) (Lepidoptera: Crambidae). Jurnal Entomologi Indonesia 6(1): 21-29.

Lynch M, Milligan BG. 1994. Analysis of population genetic structure with RAPD markers. Molocular Ecology 3: 91-99. http://dx.doi.org/10.1111/j.1365294X.1994.tb00109.x.

Manchua J, Muturi G, Gichereu G. 2007. Genetic diversity within Brachylaena huillensis (O.Hoffim) population in Kenya: implication for conservation of wood carving tree. Journal of Discovery Innovation 19: 32-36.

[MoF]. Ministry of Forestry. 2012. Forestry Statistic of Indonesia 2011. Jakarta: Ministry of Forestry.

Muchugi A, Kadu C, Kindt R, Kipruto H, Lemurt S, Olale K, Nyadoi P, Dawson I, Jamnadass R. 2008. Molecular Markers for Tropical Trees, A Practical Guide to Principles and Procedures. ICRAF Technical Manual No. 9. Dawson I and Jamnadass R. (eds.) Nairobi: World Agroforestry Centre.

Nei M. 1978. Estimation of average heterozygosity and genetic distance from a small number of individuals. Genetics 89: 583-590.

Nei M. 1973. Analysis of gene diversity in subdivided populations. Proceedings of the National Academy of Sciences of the United State of America 70: 3321-3323.

Nybom H. 2004. Comparison of different nuclear DNA markers for estimating intraspecific genetic diversity in plants. Molecular Ecology 13: 1143-1155. http://dx.doi. org/10.1111/j.1365-294X.2004.02141.x. 
Nybom H and Bartish IV. 2000. Effects of life history traits and sampling strategies on genetic diversity estimates obtained with RAPD markers in plants. Plant Ecology and Evolution Systematics 3: 93-114. http://dx.doi.org/10.1078/1433-8319-00006.

Osman A, Jordan B, Lessard PA, Muhammad N, Haron MR, Riffin NM, Sinskey AJ, Rha CK, Housman DE. 2005. Genetic Diversity of Eurycoma longifolia Inferred from Single Nucleotide Polymorphisms. Plant Physiology 131: 1294-1301. http://dx.doi.org/10.1104/pp.012492.

Rohlf FJ. 1998. NTSYSpc: Numerical Taxonomy. New York: State University of New York.

Runo MS, Muluvi GM, Odee DW. 2004. Analysis of genetic structure in Melia volkensii (Gurke.) populations using random amplified polymorphic DNA. African Journal of Biotechnology 3(8): 421-425.

Schneider S, Roessli D, Excoffier L. 2000. Arlequin Version 2.00: A Software for Publication Genetic Data Analysis. Switzerland: University of Geneva.

Spooner D, Van-Treuren R, De-Vicente MC. 2005. Molecular Markers for Gene Bank Management. IPGRI Technical Bulletin No. 10. International Plant Genetic Resources Institute, Rome, Italy.

Susilowati A. 2009. Teknik Perbanyakan dan Analisis Kekerabatan Pasak Bumi (Eurycoma longifolia, Jack). Tesis. Sekolah Pascasarjana IPB. Bogor.

Sumiyati D, Dwiyati FG, Istomo, Siregar IZ. 2009. Growth evaluation and genetic diversity of Dipterocarpus retusus blume and Dipterocarpus hasseltii blume. Based on RAPD Markers. Jurnal Manajemen Hutan Tropika 15(3): 109-116.

Tambi MI, Imran MK, Henkel RR. 2011. Standardised watersolubleextract of Eurycoma longifolia, Tongkat ali, as testosterone booster for men with late-onset hypogonadism. Andrologia 44: 226-230. http://dx.doi.org/10.1111/j.1439-0272.2011.01168.x.

Tee TT, Azimahtol HLP. 2005. Induction of Apoptosis by Eurycoma longifolia Jack Extracts. Anticancer Research 25: 2205-2214.

Wang BY, Shi L, Ruan ZY, Deng J. 2011. Genetic diversity and differentiation in Dalbergia sissoo (Fabaceae) as revealed by RAPD. Genetics and Molecular Research 10(1): 114-120. http://dx.doi.org/10.4238/vol10-1gmr 995.

Weising K, Nybom H, Wolf K, Kahl G. 2005. DNA fingerprinting in plants: principles, methods, and applications. Annals of Botany 97(3): 476-477. http://dx.doi.org/10.1201/9781420040043.

Welsh J, McClelland. 1990. Fingerprinting genomes using PCR with arbitrary primers. Nucleic Acids Research 18: 7213-7218. http://dx.doi.org/10.1093/nar/18.24.7213.

Williams JGK, Kubelik AR, Livak KJ, Rafalski JA, Tingey SV. 1990. DNA polymorphisms amplified by arbitrary primer are useful as genetic markers. Nucleic Acids Research 18 (22): $6531-6535$. http://dx.doi.org/10.1093/nar/18.22.6531.

Yeh FC, Yang R, Boyle T. 1999. POPGEN Version 1.31. Microsoft Window Based for Population Genetic Analysis. Canada: University of Alberta.

Yong JW, Xue PS, Zhang CZ. 2012. Clonal Diversity and Genetic Differentiation in Rhizomatous Herb, Iris japonica (Iridaceae) Populations on Jinyun Mountain, Southwest China. Sains Malaysiana 41(2): 149-154.

Zulfahmi. 2007. Genetic Variation Assessment of Maesopsis eminii Using Random Amplified Polymorphisms DNA (RAPD) Marker. In: Proceeding Symposium on Forest and Land Rehabilitation in Indonesia. Jakarta, 5-7 Februari, 2007.pp 7-14. 